\title{
Agricultural Pesticides Used in Eskişehir and Kütahya Population Areas of Great Bustard (Otis tarda, Linnaeus, 1758)
}

\author{
Muharrem KARAKAYA¹, Mehmet Mahir KARATAŞ1* ${ }^{*}$ Ünal ÖZELMAS1
}

${ }^{1}$ Eskişehir Osmangazi University, Faculty of Science and Letters, Biology Department, Meşelik Campus, Eskişehir, Turkey

\begin{abstract}
Received: 03.12.2017
Accepted: 26.12 .2017

Available online: 28.12 .2017

Published: 29.12.2017

Abstract: The habitat of the Great Bustard (Otis tarda, Linnaeus, 1758) in our country, due to the change of agricultural land to the natural and secondary steppe, nowadays constitutes mostly farmland. In addition to the pest control in the field of agriculture and indirectly to get more products from agricultural areas, wide variety of pesticides (Herbicides, Rodenticides, Insecticides, etc.) are used. In this study, it has been aimed to identify what agricultural pesticides are used in the living areas of the species and based on these findings the possible effects on this species are compared with the previous literature. This study was carried out in Eskişehir Aliken Important Nature Area and Kütahya Altıntaş Wildlife Development Area between March 2013 and May 2017. During the field survey in the habitat of great bustard, it was determined that 13 different active ingredients of herbicide, 3 different active ingredients of insecticide, and 2 different active ingredients of fungicide were used and these pesticides' photographs were taken and coordinates were noted. Finally, the written articles on the determined pesticide active ingredients were scanned and potential impacts on these endangered species are discussed
\end{abstract}

Keywords: ecotoxicology, insecticide, herbicide, vulnerable, great bustard

\section{Eskişehir ve Kütahya'daki Toy Kuşu (Otis tarda, Linnaeus, 1758)'nun Yaşam Alanlarında Kullanılan Tarımsal İlaçlar}

Özet: Ülkemizde Toy Kuşu (Otis tarda, Linnaeus, 1758)'nun yaşam alanları, doğal ve ikincil bozkırların tarım alanlarına dönüştürülmesinden dolayı, günümüzde çoğunlukla tarım arazileri oluşturmaktadır. Yine günümüzde tarım alanlarındaki zararlılarla mücadele etmek ve dolaylı olarak tarım alanlarından daha fazla ürün almak için çok çeşitli tarım ilaçları (Herbisit, Rodentisit, İnsektisit vb.) kullanılmaktadır. Bu çalışmada bu türün yaşam alanları içerisinde kullanılan tarım ilaçlarının neler olduğu belirlenerek elde edilen bulgularla literatür karşılaştırması da yapılarak bu ilaçların bu tür üzerindeki olası etkilerinin tartışılması amaçlanmışıı. Bu çalışma, Mart 2013-Mayıs 2017 tarihleri arasında Eskişehir ili Aliken Önemli Doğa Alanı (ÖDA) ve Kütahya İli Altıntaş Yaban Hayatı Geliştirme Sahası (YHGS) içinde gerçekleştirilmiştir. Yapılan arazi çalışmaları sırasında Toy kuşunun yaşam alanları içinde kullanılan 13 farklı herbisit aktif maddesi, 3 farklı insektisit aktif maddesi ve 2 farklı fungisit aktif maddesi belirlenmiş, fotoğraflanmış ve koordinatları alınmıştır. Son olarak belirlenen bu tarımsal ilaçların etken maddeleri üzerine yapılan makaleler taranmış ve nesli tehlikede olan bu tür üzerine oluşturacağı olası etkileri tartışılmıştır.

Anahtar kelimeler: ekotoksikoloji, insektisit, herbisit, hassas tür, toy kuşu

\section{Introduction}

The Great Bustard is the biggest species in the Western Palearctic species of the Otididae and the species is a steppe bird inhabiting cereal farmland (Alonso et al. 2001, Lopez-Jamar et al. 2010, Lemus et al. 2011). It is a globally threatened species classified as 'Vulnerable' (Palacin and Alonso 2008, Bravo et al. 2012, Palacin et al. 2012, Tanriverdi Bahar 2015, Avc1 et al. 2017, IUCN 2017) and is listed in the CITES Appendix II with a wide distribution area ranging from Eastern Asia Westwards to Iberia and Northern Morocco (Alonso et al. 2003, Barati and Amerifar 2008, Horreo et al. 2013, Karataş et al. 2015, Tanriverdi Bahar 2015, Avc1 et al. 2017). In the last decades, farmland birds in Europe and North America have been suffering population declines at higher rates than birds from other habitats (Lopez-Jamar et al. 2010, EBCC 2014, Karataş et al. 2015). Farmland is being profoundly altered through agricultural intensification, posing a major challenge for biodiversity conservation today in many countries (Krebs et al.1999, Karataş et al. 2015). Recent studies have pointed out that a major cause of bird population decline is the use of pesticides, either because of the indirect effects on habitat and food supply (Moreby and Sourthway 1999,
Hallmann et al.2014, Goulson 2014) or because of the direct toxic effects on the health of birds (Mineau and Whiteside 2013). A greater probability of lethality in birds occurs when the ratio between the LD50 and the estimated field exposure dose is low (EFSA 2009). Pesticides with higher LD50 or lower risk of exposure can produce a range of sublethal effects such as loss of physical condition, immunosuppression, neurological impairments, or endocrine disruption (Fry 1995, Karataş et al. 2015). Also use of fungicides is on the rise and their extensive and indiscriminate use is a cause for concern as; (i) they may have a longer half-life, (ii) their residues are also toxic, and (iii) a major part of fungicides reaches non-target organisms (Meenakshi et al. 2007). All these effects may ultimately affect survival or reproduction, and; therefore, impact population dynamics (Karataş et al. 2015, LopezAntia et al. 2015).

Great Bustards are omnivorous, with the main dietary components consisting of green plant material, arthropods, and seeds (Lane et al. 1999), and prey infrequently and opportunistically on small vertebrates (Amphibia, lizards, chicks of ground-nesting birds and rodent such a Voles Microtus sp.) (Lane et al. 1999, Lemus 
et al. 2011). Rodent consumption has not been observed in Iberian great bustards but has been reported for central European populations (Lemus et al. 2011). Thus, both treated seeds (wheat, barley) and poisoned animals (rodent, lizards) may potentially form part of their diet (Lemus et al. 2011, Karataş et al. 2015).

In this study, it has been aimed to identify what agricultural pesticides are used in the living areas of the species and the possible effects on this species are compared with the previous literature. First, we determined used pesticides in the habitat of Great Bustard between March 2013 and May 2017 in Eskişehir Aliken Important Nature Area and Kütahya Altıntaş Wildlife Development Area. Finally, we scanned the written articles on the determined pesticides active ingredients and we discuss the potential impacts on these endangered species.

\section{Materials and Methods}

\subsection{Study Area}

Kütahya Altıntaş Wildlife Development Area is located in the South of Kütahya, with coordinates $39^{\circ} 04^{\prime}-39^{\circ} 12^{\prime} \mathrm{N}$, $29^{\circ} 55^{\prime}-30^{\circ} 08^{\prime} \mathrm{E}$ and its total area is 15.040 hectares. Altitude of the area varies between 1000-1414 meters. The current status of the area is Wildlife Development Area and there are approximately 12 villages within the area with a total population of 5000. Continental climate dominates the area; thus, summers are hot and dry and winters are cold and rainy. Average annual temperature is $10,7^{\circ} \mathrm{C}$, the average annual sunshine duration is 69,5 days, the number of average annual rainy days is 120,5 , average annual rainfall is $547,3\left(\mathrm{~kg} / \mathrm{m}^{2}\right)$, average annual relative humidity is $58 \%$. Highest average temperature occurs in July and August, while lowest average temperatures occur in January and February. This area is one of the important population areas of the Great Bustard in western Turkey as it has the status of Wildlife Development Area. However, Altıntaş plain isone of the 97 Important Bird Areas (Yarar and Magnin 1997, Karataş and Özelmas 2013).

Aliken important Nature Area (INA) is a semiagricultural region which is located between Çifteler and Sivrihisar in Eskişehir/Turkey, with coordinates $39^{\circ} 11^{\prime}$ $39^{\circ} 24^{\prime} \mathrm{N}, 31^{\circ} 09^{\prime}-31^{\circ} 24^{\prime} \mathrm{E}$ and its total area is 19.665 hectares (Karataş et al. 2015). Altitude of the area varies between $830-880$ meters. It is surrounded by Aliken stream in the north, and Seydi stream in the south, which are both the branches of Sakarya river system. There are uncultivated stony and marsh areas, fallow lands, and cultivated areas. At the stony areas, animal breeding is performed, while on the cultivated areas, dry farming of plants such as graminae, chickpea (Cicer arietinum), and safflower (Carthamus tinctorius) is performed. However, within the area, irrigated farming of beet (Beta vulgaris), potato (Solanum tuberosum), pumpkin (Cucurbita moschata), and opium poppy (Papaver somniferum) is performed partly (Karataş et al. 2015). Although there is not an officially recognized status of the area, it ranks as one of the important bustard breeding areas in the National Bustard Action Plan.

\subsection{Method}

In the study area, field surveys were carried out between March 2013 and May 2017, 132 days in total. The study area was divided into squares of $1 \times 1 \mathrm{~km}$ and field scanning was made by walking through each square for finding used empty boxes. When empty boxes were found, date, hour, geographical coordinates, habitat type, name, and the number of boxes were recorded.

Also, by conducting interviews with the officers who supply agricultural pesticides to local farmers, information was gathered about which pesticides are sold in the area. According to finding used empty boxes and sold brand of pesticides, we identified active ingredients of pesticides (Karataş et al. 2015).

\section{Results and Discussions}

During the study, we identified 11 different brands of herbicide, 6 different brands of insecticide and 1 different brand of fungicide.

Eleven different brands of herbicide have 13 different active ingredients as Bentazone, Propoxycarbazonesodium, Mesosulfuron-methyl, Phenmedipham, Ethofumesate, Imazamox, Desmedipham, Tribenuronmethyl, Dichloropicolinic acid, 2,4-D, Florasulam, Trifluralin, and 2,4-D isooctyl ester. Phenmedipham and Desmedipham are Bis-Carbamate, Ethofumesate is a Benzofuran, Trifluralin is a Dinitroaniline, 2,4-D and 2,4-D isooctyl ester are Chlorophenoxy, Florasulam is a Triazolopyrimidine, Bentazone is a Benzothiazinone, Imazamox is an Imidazolinone, Propoxycarbazonesodium is a Triazolone, Mesosulfuron-methyl is a Sulfonylurea compound.

Six different brands of insecticide have 3 different active ingredients as Deltamethrin, Cypermethrin alpha, and Chlorpyrifos-ethyl. Deltamethrin and Cypermethrin alpha is a Pyrethroid compound and Chlorpyrifos-ethyl is an Organophosphorus compound.

One different brand of fungicide has 2 different active ingredients as Mandipropamid and Difenoconozole. Mandipropamid is a Mandelamide and Difenoconazole is a Triazole compound.

We did not identify any brand of rodenticide, nematicide, molluscicides, and acaricide.

Mesosulfuron-methyl belongs to the class of chemicals called sulfonyl ureas. The chemical works by inhibiting the enzyme acetolactate synthase (ALS) that leads to the depletion of key amino acids that are necessary for protein synthesis and plant growth. A chronic reproductive effect (reduced number of live embryos to viable embryos) was observed in mallard duck (USEPA 2004). No chronic reproductive effect was observed in the other bird species tested (bobwhite quail). It was practically non-toxic on an acute basis for the bobwhite quail and mallard duck (LD50 > 2,000 mg/kg), mammals (LD50 >7000 ppm), honey bee (LD50 > $13 \mathrm{ug} /$ bee), and estuarine/marine fish (LC50 > $105 \mathrm{ppm}$ ). It was practically non-toxic to the bobwhite quail and mallard on a subacute basis (LC50 > 4,750 ppm). It was presumably nontoxic on a chronic basis to estuarine/marine fish based on the high LC50s. No chronic or reproductive effects were observed in mammals (NOAEL of 1,000 ppm) (USEPA 2004).

Imazamox is relatively non-toxic by oral and inhalation routes, slightly toxic by the dermal route, nonto-slightly irritating to the skin, and slightly-to-moderately irritating to the eye. Imazamox is not a dermal sensitizer. Imazamox is practically nontoxic to mallard duck and bobwhite quail (but any information about toxicology for 
other birds), finfish, aquatic invertebrates, and honeybees (USEPA 1997). However, it was hazardous for the birds, fish, aquatic invertebrates, bees, earthworms, and soil microbes, even with the worst case assumptions, .e. direct overspray, was determined to be insignificant. In acute oral and dietary toxicity tests on the mallards and Bobwhite quail conducted to meet USEPA requirements, there was no treatment-related effects at the maximum doses used, approximately $2000 \mathrm{mg} / \mathrm{kg}$ bw and 5000 $\mathrm{mg} / \mathrm{kg}$ (in feed) respectively. There were no effects in the long term reproductive studies at $2000 \mathrm{mg} / \mathrm{kg}$ in the feed. In conclusion, Imazamox is practically non-toxic to birds. (NRA 2000)

The Syngenta fungicide, mandipropamid belonging to the CAA (Carboxylic Acid Amide) fungicide group was first registered in the UK in 2007 as 'Revus' for the control of potato late blight (Cooke and Little 2010). It is specifically active against Oomycete pathogens and has a high affinity for the wax layer on leaf surfaces (Cooke and Little 2010, USEPA, 2008). Mandipropamid is practically nontoxic for birds on an acute oral and acute dietary basis. Mandipropamid did not cause any significant chronic effects on reproduction or growth and survival of chicks at 1060 ppm a.i. which was the highest concentration tested (USEPA 2008).

The triazole compounds are the largest and most important group of systemic compounds developed for fungal disease in plants. Triazole compounds are mainly used as growth retardants and also as the stress protectants in many crops. Many of the triazole compounds have both fungi toxic and plant growth regulating properties (Jaleel et al. 2008). They tend to be much more effective than many other plant growth regulators and generally require blow rate of application (Pinhero et al. 1997). More recently, it has been found out that the triazole compounds are able to protect plants from the environmental stress conditions (Asare-Boamah et al. 1986). The triazole mediated stress protection is often explained in terms of hormonal changes such as an increase in cytokinins, a transient rise in ABA, and a decrease in ethylene (Mackay et al. 1990, Pathak et al. 2009, Shanmugapriya et al. 2013).

Difenoconazole is a broad-spectrum fungicide used for disease control in many fruits, vegetables, cereals, and other field crops (Meenakshi et al. 2007, Shanmugapriya et al. 2013). It has preventive and curative effect. Difenoconazole acts by inhibition of demethylation during ergosterol synthesis; it is a DMI fungicide. This fungicide is toxic for fish, mammals, and aquatic invertebrates. Difenoconazole exhibits some evidence of neurotoxicity in the database but the effects are transient or occur at doses exceeding the limit dose. It is not mutagenic and it is not a developmental or reproductive toxicant. Chronic effects in rats and mice are seen as cumulative decreases in body weight gains. No evidence of carcinogenicity was seen in rats. Evidence for carcinogenicity was seen in mice where liver tumors were induced at doses which were considered to be excessively high for carcinogenicity testing. (USEPA 2017).

Although, Ecotoxicology of difenoconazole is LD50 (9-11 d) >2150 mg/kg and LC50 >4760 ppm in some bird species (USEPA 2017), to the best of our knowledge, no major deleterious effects of this active ingredient have been reported so far on Great Bustard. The available information points to a low toxicity of difenoconazole on birds, with oral LD50s higher than 2,000 mg/ kg in mallard duck, bobwhite quail, and Japanese quail (Lopez-Antia et al. 2013). Unlike other pesticides, difenoconazole hardly caused any effect on body condition or biochemical parameters; the fungicide only reduced total protein concentration and phosphorus levels, which in birds has a poor diagnostic value. Accordingly, the only compound for which immunotoxic effects were not detected was difenoconazole. Although, to our knowledge, no study had related the exposure to this fungicide to egg quality, difenoconazole both reduced fertile eggs rate and caused abnormally small eggs, with a narrower and thinner shell (Lopez-Antia et al. 2013).

Most of the carbamate compounds such as Phenmedipham and Desmedipham are toxic for the most bird species (Baril et al. 1994). Carbamate-induced acute and chronic intoxication of non-target wildlife species result in neurophysiological and behavioral changes in food consumption, thermoregulation, and reproduction (Engelman et al. 2012, Jiang et al. 2013, Karatas et al. 2015).

Bentazone is regarded as slightly toxic according to WHO guideline. According to animal models, its noobserved adverse-effect level (NOAEL) dose of systemic toxicity is $3600 \mathrm{mg} / \mathrm{kg}$. Bentazone has diuretic and anticoagulant effect as toxicity (WHO 2011). Lethal doses may cause dispnea, central nervous system depression, fever, and neuroleptic malign syndrome in animals. Bentazone intoxication may induce vomiting, fever, perspiration, muscle rigidity, sinus tachycardia, somnolence, leukocytosis, rhabdomyolysis, renal and hepatic damage (Thomas and Ibels 1985, Neuschl et al. 1992, Muller et al. 2003). As a result of bentazone metabolism, it is thought that unstable $\mathrm{OH}$ - radicals occur. These free radicals form of oxidative stress, bind to cell proteins and this process result in organ damage. In addition, Bentazone is a nephrotoxic agent as it includes benzothiadiazine acting as a diuretic. Benzothiadiazine increases the blood urea by reducing hepatic glucose production in rats and benzothiadiazine is an inhibitor of oxidative mechanisms. Bentazone-induced acute renal failure may develop as a result of renal hypoperfusion due to severe vomiting, rhabdomyolysis, and direct nephrotoxic effect of the agent (Huber and Otto 1994, Wu et al. 2008, Emre et al. 2011).

Chlorophenoxy herbicides such as 2,4-D, exhibit a variety of mechanisms of toxicity, including dosedependent cell membrane damage leading to central nervous system toxicity, interference with cellular metabolism involving acetyl-coenzyme A (CoA), and uncoupling of oxidative phosphorylation due to either the disrupted CoA activity or cellular membrane damage (NPIC 2015). For more detailed information, see Karatas et al. (2015).

Embryotoxicity has been observed in duck eggs exposed to herbicides via immersion in aqueous emulsions in the laboratory (Hoffman and Albers 1984) and Trifluralin was more embryotoxic than some other herbicides and insecticides (Freemark and Boutin 1995).

In birds, many studies have investigated the chronic toxicity of chlorpyrifos and have noted adverse effects on fertility, hatchability, embryonic deformities, and bodyweight (Schom et al. 1973, Gile and Eyers 1986). Intoxication of chlorpyrifos produced hematobiochemical 
and histopathological alterations in broiler birds (Ahmad et al. 2015). For more detailed information, see Karatas et al. (2015).

According to Karatas et al. (2015), in vegetable, tobacco, households, cotton, cereals, and other crops throughout the world, pyrethroids are widely used as insecticides. Also they are widely applied for the control of ectoparasites of domestic animals (Ural and Sağlam 2005, Chu et al. 2007, Enayati et al. 2010). For pyrethroids, the primary target sites are the voltage-gated sodium channels (VGSCs) (Jin et al. 2010, Rinkevich et al. 2012, Rinkevich et al. 2013, Karatas et al. 2015, Nieradko-Iwanicka and Borzecki 2016). Pyrethroids exert neurotoxicity by binding to and delaying the inactivation (closing) of the sodium channels, resulting in convulsions, prostration, and ultimately death (Werner and Moran 2008, Yang et al. 2014). Based on the chemical structure, pyrethroids are divided into type I and type II (US Environmental Protection Agency (USEPA 2010). Cypermethrin (CP) and Deltamethrin, a type II pyrethroids, are one of the top five pyrethroids in use (Oros and Werner 2005, Bhanu et al 2011, Güneş and Yerli 2011, Nieradko-Iwanicka and Borzecki 2016). For over half a century, it was believed that pyrethroids acted only via fast disregulation of the nervous system without any significant cytotoxic effect. However, there is evidence that exposure to pyrethroids may produce neuron death in adult animals (AbdelRahman 2001, 2004), inhibition of nervous system development in rodent newborns (Cantalamessa 1993, Imamura et al. 2002), and damage to internal organs via toxic metabolites (Casida et al. 1975, Shono et al. 1979). Recent studies show that pyrethroids impair kidney functioning, cause hepatic toxicity, change blood morphology, disrupt the endocrine system, and lead to oxidative stress (Nieradko-Iwanicka and Borzecki 2016). According to Galal et al. 2014, Deltamethrin produces oxidative stress, as they showed that exposure to deltamethrin caused a significant increase in lipid peroxidation, nitric oxide concentration, and DNA fragmentation percentage, plus a significant reduction of total antioxidant capacity of deltamethrin-treated groups of rats. Also according to Yildirim et al. 2006 and Güneş and Yerli 2011, Deltamethrin causes severe morphological alterations in the gills and liver and causes toxic effects on the haemobiotic organs, liver, and gills. Also deltamethrin has an adverse inhibitory effect on the lipase enzyme activity in Poecilia reticulata. Because of the widespread use of deltamethrin that may lead to the exposure in natural ecosystems is likely to have a negative effect on nutrition and physiological condition in wild fish (Güneş and Yerli 2011). In conclusion, deltamethrin produces oxidative stress in the livers and, to a lesser degree, in the kidneys of exposed animals (Nieradko-Iwanicka and Borzecki 2016). On the other hand, Cypermethrin is less acutely toxic for birds (LD50 > 1000) but their broad spectrum toxicity to invertebrates may cause depletion of important avian food resources (Boutin et al. 1999, Karatas et al. 2015).

According to Birdlife (2015), Bird species that use arable farmland are at risk of exposure to insecticides. Granivorous passerines may consume pesticide-treated seeds (primary poisoning). Scavengers and predators are poisoned when they consume contaminated prey (secondary poisoning), e.g., secondary poisoning by carbamate and organophosphate insecticides has been attributed as the cause of mortality in barn owls and kestrels. Also, species that regularly feed on earthworms are also more likely to be poisoned as a result of carbamate use. Small amounts of these insecticides can cause sublethal effects, such as reduced activity in birds that spend more time resting or perching than foraging or reproducing. However, sub-lethal toxicity associated with exposure to organophosphates and carbamates can also lead to alteration in migratory behaviour such as a lack of migratory orientation.

Although during the study period, we did not find any brand of rodenticide or active ingredient, rodenticides increase in parasite and pathogen burden of intoxicated individuals and raise concern about possible effects on the health or even survival of the birds. High parasite loads have been shown to affect reproductive rates and survival of several bird species (Lemus et al. 2011, Karatas et al. 2015). Also, birds that forage in agricultural landscapes can be exposed to anticoagulant rodenticides (ARs). Especially many raptor species are likely to be exposed to rodenticides due to a regular diet of rodents. Scavenging species may be especially at risk because they feed on carcasses that could be contaminated with rodenticides. The red kite, for example, may be particularly susceptible to secondary poisoning because of the high proportion of carrion in its diet, including rat carcasses (Birdlife 2015).

As the result of the literature comparison, when we look at the effects of the pesticides used in the area we see that (1) herbicides eliminate plants (weeds and nonweeds) whose seeds are important for Great Bustard (Cotton thistle "Onopordum acanthium") and reduce suitable nestling cover in an already depauperate agricultural landscape (2) these pesticides cause disturbance and attention loss in the species because of the retention of some rodenticide and insecticide in tissues through the nutrition and; therefore, it causes species to crash electrical transmission lines and leads to the destruction of species, (3) they decrease the quality of fertility and sperm of the this species (4) they cause the intensity of parasits and variation of the species; thus, it effects the life quality and longevity in a negative way, (5) insecticides decreased chick survival through direct toxicity to the insect food preferred by Great Bustard chicks (direct observation), 6) by decreasing plant diversity in non-crop habitats, herbicides also reduce arthropod populations for this species which rely on large supplies of invertebrates to feed their young, (7) they caused a reduction in the diversity of nutrients such as nutritional competition that may lead to adverse effects. Accordingly, this study suggests that pesticide abuses could represent a serious threat of intoxication and mortality in an important threatened bird such as the Great Bustard. The results also highlight the importance of considering sub-lethal effects of coated seed ingestion by farmland birds, even at recommended doses of pesticide use, in terms of their physiological and reproductive effects. Thus, these pesticides used should be either restricted or totally prohibited in the Great Bustard's -that are endangered on a global scale- inhabited areas.

Acknowledgements: This study was supported by 201319008 and 201619A232 coded projects by Eskişehir Osmangazi University Scientific Search Project Commission in Turkey.

\section{References}

Abdel-Rahman, A., Shetty, A. K., Abu-Donia, M. B. 2001: Subchronic dermal application of N,N-diethyl m-toluamide (DEET) and permethrin to adult rats, alone or in combination, causes diffuse neuronal cell death and cytoskeletal abnormalities in the cerebral cortex 
in the hippocampus, and Purkinje neuron loss in the cerebellum. Experimental Neurology, 172: 153.

Abdel-Rahman, A., Dechkovskaia, A. M., Goldstein, L. B., Bullman, S. H., Khan, W., El Masry, E. M. 2004: Neurological deficits induced by malathion, DEET, and permethrin, alone or in combination in adult rats. Journal of Toxicology \& Environmental Health A, 67: 331.

Ahmad, M. Z., Khan, A., Javed, M. T., Hussain, I. 2015: Impact of chlorpyrifos on health biomarkers of broilerchicks. Pesticide Biochemistry and Physiology. doi: 10.1016/j.pestbp.2014.12.024.

Alonso, J. A., Martin, C. A., Alonso, J. C., Morales, M. B., Lane, S. J. 2001: Seasonal movements of male Great Bustards in Central Spain. Journal of Field Ornithology, 72(4): 504-508.

Alonso, J. C., Martin, C. A., Palacin, C., Magana, M., Martin, B. 2003: Distribution, size and recent trends of the Great Bustard (Otis tarda) population in Madrid Region, Spain. Ardeola, 50(1): 21-29.

Asare-Boamah, N. K., Hofstra, G., Fletcher, R. A., Dumbroff, E. B. 1986: Triadimefon protects bean plants from water stress through its effects on ABA. Plant and Cell Physiology, 27: 383-390.

Avcı, F., Adızel, Ö., Azizoğlu, E. 2017: A Study On Ornithofauna of Muş Plain. Adıyaman Üniversitesi Tarımsal Uygulama ve Arazi Yönetimi Uygulama ve Araştırma Merkezi, Cilt 5, Sayı 1: 20-32.

Barati, A. and Amerifar, A. A. 2008: On the status of the Great Bustard (Otis tarda) Linnaeus, 1758 (Aves: Otididae) in Kurdistan Province, İran. Zoology in the Middle East, 43: 41-48.

Baril, A., Jobin, B., Mineau, P., Collins, B. T. 1994: A consideration of interspecies variability in the use of the median lethal dose (LD50) in avian risk assessment, Canadian Wildlife Service Technology Report No. 216. Environment Canada, Hull, Quebec.

Bhanu, S., Archana, S., Ajay, K., Bhatt, J. L., Bajpai, S. P., Singh, P. S., Vandana, P. 2011: Impact of Deltamethrin on Environment, use as an Insecticide and its Bacterial degradation-A preliminary study. International Journal Of Environmental Sciences, Volume 1, No 5.

Birdlife International, 2015: BirdLife Europe position paper: reducing direct and indirect impacts of pesticides on birds, http://www.birdlife.org/sites/default/files/attachments/ 20150504_ATF-pesticides-position.pdf (Date of access: 30.11.2017).

Boutin, C., Freemark, K. E., Kirk, D. A. 1999: Farmland birds in southern Ontario: field use, activity patterns and vulnerability to pesticide use. Agriculture, Ecosystems and Environment, 72: 239-254.

Bravo, C., Ponce, C., Palacin, C., Alonso, J. C. 2012: Diet of young Great Bustards Otis tarda in Spain: sexual and seasonal differences. Bird Study, iFirst: 1-9.

Cantalamessa, F. 1993: Acute toxicity of 2 pyrethroids, permethrin and cypermethrin in neonatal and adult rats. Archives of Toxicology, 67: 510.

Casida, J. E., Ueda, K., Gaughan, L. C., Jao, L. T., Soderlund, D. M. 1975: Structure- biodegradability relationships in pyrethroid insecticides. Archives of Environmental Contamination and Toxicology, 3: 491.

Chu, S., Henny, C. J., Kaiser, J. L., Drouillard, K. G., Haffner, G. D., Letcher, R. J. 2007: Dacthal and chlorophenoxy herbicides and chlorothalonil fungicide in eggs of osprey (Pandion haliaetus) from the Duwamish-Lake Washington-Puget Sound area of Washington state, USA. Environmental Pollution, 145: 374-381.

Cooke, L. R., Little, G. 2010: Evaluation of mandipropamid for the control of potato late blight in Northern Ireland. Twelfth Euro Blight workshop Arras, 3-6 May, France.

European Bird Census Council (EBCC), 2014: http://www.ebcc.info/ (accessed 20.05.14)

Emre, H., Keles, M., Uyanık, A., Emet, M., Bilen, Y., Bayraktutan, D. 2011: Rhabdomyolysis and acute renal failure as a result of bentazone intoxication. Eastern Journal of Medicine, 16: 59-61.

Enayati, A. A., Asgarian, F., Amouei, A., Sharif, M., Mortazavi, H., Boujhmehrani, H., Hemingway, J. 2010: Pyrethroid insecticide resistance in Rhipicephalus bursa (Acari, Ixodidae). Pesticide Biochemistry and Physiology, 97: 243-248.

Engelman, C. A., Grant, W. E., Mora, M. A., Woodin, M. 2012: Modelling effects of chemical exposure on birds wintering in agricultural landscapes: The western burrowing owl (Athene cunicularia hypugaea) as a case study. Ecological Modelling, 224: 90- 102.
European Food Safety Authority (EFSA), 2009: Guidance document on risk assessment for birds \& mammals on request from EFSA. EFSA Journal, 7(12): 1438 .

Freemark, K. and Boutin C. 1995: Impacts of agricultural herbicide use on terrestrial wildlife in temperate landscapes: A review with special reference to North America. Agriculture, Ecosystems and Environment, 52: 67-91.

Fry, D. M. 1995: Reproductive effects in birds exposed to pesticides and industrial chemicals. Environmental Health Perspectives, 103 (Suppl7): 165-171.

Galal, M. K., Khalaf, A. A., Ogaly, H. A., Ibrahim, M. A. 2014: Multimechanistic neuroprotective effect of vitamin E against deltamethrin induced brain toxicity. Toxicology Report, 2014 http://dx.doi.org/10.1016.j.toxrep.2014.09.008.

Gile, J. D. and Eyers, S. M. 1986: Effect of adult mallard age on avian reproduction tests, Archives of Environmental Contamination and Toxicology, 15: 751-756.

Goulson, D. 2014: Ecology: pesticides linked to bird declines. Nature, 511 295-296.

Güneş, E. and Yerli, S. V 2011: Effects of Deltamethrin on Lipase Activity in Guppies (Poecilia reticulata). Turkish Journal of Fisheries and Aquatic Sciences, 11: 473-476.

Hallmann, C. A., Foppen, R. P. B., Van Turnhout, C. A. M., De Kroon, H., Jongejans, E. 2014: Declines in insectivorous birds are associated with high neonicotinoid concentrations. Nature, 51: 341-343.

Huber, R. and Otto, S. 1994: Environmental behavior of bentazon herbicide. Reviews of Environmental Contamination and Toxicology, 137: 111134 .

Hoffman, D. J. and Albers, P. H. 1984: Evaluation of potentia embryotoxicity and teratogenicity of 42 herbicides, insecticides, and petroleum contaminants to mallard eggs. Archives of Environmental Contamination and Toxicology, 13:15-27.

Horreo, J. L., Palacin, C., Alonso, J. C., Mila, B. 2013: A link between historical population decline in the threatened great bustard and human expansion in Iberia: evidence from genetic and demographic data. Biological Journal of the Linnean Society, 110: 518-527.

Imamura, L., Hasegawa, H, Kurashina, K, Matsuno, T, Truda, M. 2002: Neonatal exposure of newborn mice to pyrethroid (permethrin) represses activity-dependent c-Fos mRNA expression in cerebellum. Archives of Toxicology, 76: 392.

Jaleel, C. A., Gopi, R., Kishorekumar, A., Manivannan, P., Sankar, B. Panneerselvam, R. 2008: Interactive effect of triadimefon and salt stress on antioxidative status and ajmalicine accumulation in Catharanthus roseus. Acta Physiologiae Plantarum, 30: 287-292.

Jiang, Y., Swale, D., Carlier, P. R., Hartsel, J. A., Ma, M., Ekström, F., Bloomquist, J. R. 2013: Evaluation of novel carbamate insecticides for neurotoxicity to non-target species. Pesticide Biochemistry and Physiology, 106: 156-161.

Jin, T., Zeng, L., Lu, Y, Xu, Y, Liang, G. 2010: Identification of resistanceresponsive proteins in larvae of Bactrocera dorsalis (Hendel), for pyrethroid toxicity by a proteomic approach. Pesticide Biochemistry and Physiology, 96: 1-7.

Karataş, M. M. and Özelmas, Ü. 2013: The study on the population of Great Bustard (Otis tarda) in Altıntaş plain, Kütahya/Turkey. Biological Diversity and Conservation, 6(3): 92-96.

Karataş, M. M., Karakaya, M., Özelmas, Ü. 2015: Agricultural pesticides used on Central West Anatolian (Eskişehir/Turkey) population areas of Great Bustard (Otis tarda). Biological Diversity and Conservation, 8(3): 254-258.

Krebs, J. R., Wilson, J. D., Bradbury, R. B., Siriwardena, G. M. 1999: A second silent spring?. Nature, 400: 611-612.

Lane, S. J., Alonso, J. C., Alonso, J. A., Naveso, M. A. 1999: Seasonal changes in diet and diet selection of Great Bustards (Otis t. tarda) in North-West Spain. Journal of Zoology, 247: 201-214.

Lemus, J. A., Bravo, C., Garcia-Montijano, M., Palacin, C., Ponce, C., Magana, M., Alonso, J. C. 2011: Side effects of rodent control on nontarget species: rodenticides increase parasite and pathogen burden in Great Bustards. Science of the Total Environment, Volume 409, Issue 22: 4729-4734.

Lopez-Antia, A., Ortiz-Santaliestra, M. E., Mougeot, F., Mateo, R. 2013: Experimental exposure of red-legged partridges (Alectoris rufa) to seeds 
coated with imidacloprid, thiram and difenoconazole. Ecotoxicology, 22: 125. https://doi.org/10.1007/s10646-012-1009-x.

Lopez-Antia, A., Ortiz-Santaliestra, M. E., Mougeot, F., Mateo, R. 2015: Imidacloprid-treated seed ingestion has lethal effect on adult partridges and reduces both breeding investment and offspring immunity. Environmental Research, 136: 97-107.

Lopez-Jamar, J., Casas, F., Diaz, M., Morales, M. B. 2010: Local differences in habitat selection by Great Bustards (Otis tarda) in changing agricultural landscapes: implications for farmland bird conservation. Bird Conservation International: 1-14, doi:10.1017/S0959270910000535.

Mackay, C. E., Hall, J. C., Hofstra, G., Fletcher, R. A. 1990: Uniconazole induced changes in abscisic acid, total amino acids and proline in Phaseolus vulgaris. Pesticide Biochemistry and Physiology, 37: 74-82.

Meenakshi, S. N., Jeyeramraja, P. R., Manian, R. 2007: Degradation of the fungicides, Azoxystrobine and Difenoconazole in soil and their influence on soil microbial activity. Pest Technology, 1(2): 133-138.

Mineau, P. and Whiteside, M. 2013: Pesticide acute toxicity is a better correlate of U.S. grassland bird declines than agricultural intensification. PLoS One, 8: e57457.

Müller, I. B., Willads Petersen, H., Johansen, S. S., Theilade, P. 2003: Fatal overdose of the herbicide bentazone. Forensic Science International, 135: $235-236$

Moreby, S. J. and Southway, S. E. 1999: Infuence of autumn applied herbicides on summer and autumn food available to birds in winter wheat fields in southern England. Agriculture, Ecosystems and Environment, 72: 285-297.

Neuschl, J., Kacmar, P., Legath, J., Toma, S. J. 1992: The effect of Bentazone, a Czechoslovak developmental herbicide, on health status indicators in sheep during subchronic poisoning. Veterinary Medicine, 37: 161-167.

Nieradko-Iwanicka, B. and Borzecki, A. 2016: How Deltamethrin Produces Oxidative Stress in Liver and Kidney. Polish Journal of Environmental Studies, 25(3): 1367-1371

National Pesticide İnformation Center (NPIC), 2015: National Pesticide Information Center, 2,4-D Technical Fact Sheet.

National Registration Authority (NRA), 2000: Evaluation of the new active Imazamox in the products Raptor Herbicide \& Raptor Wg Herbicide. NRA Refs. 50853 \& 50854, National Registration Authority for Agricultural and Veterinary Chemicals, PO Box E240, Kingston ACT 2604 Australia.

Oros, D. R. and Werner, I. 2005: Pyrethroid Insecticides: An Analysis of Use Patterns, Distributions, Potential Toxicity and Fate in the SacramentoSan Joaquin Delta and Central Valley. SFEI Contribution 415 San Francisco Estuary Institute, Oakland, CA.

Palacin, C., Alonso, J. C., Martin, C. A., Alonso, J. A. 2012: The importance of traditional farmland areas for steppe birds: a case study of migrant female Great Bustards Otis tarda in Spain. Ibis, 154: 85-95.

Palacin, C., Alonso, J. C. 2008: An updated estimate of the world status and population trends of the Great Bustard (Otis tarda). Ardeola, 55(1): 1325 .

Pathak, M. K., Bihari, V., Mathur, N., Srivastava, A.K. 2009: Adverse health effects of pesticides in agrarian populations of developing countries. Review of Environmental Contamination and Toxicology, 200: 33-52.

Pinhero, R. G., Rao, M. P., Paliyath, G., Murr, D. P., Fletcher, R. A. 1997: Changes in activities of antioxidant enzymes and their relationship to genetic and paclobutrazol induced chilling tolerance of maize seedlings. Plant Physiology, 114: 695-704.

Rinkevich, F. D., Du, Y., Dong, K. 2013: Diversity and convergence of sodium channel mutations involved in resistance to pyrethroids. Pesticide Biochemistry and Physiology, 106: 93-100.

Rinkevich, F. D., Su, C., Lazo, T. A., Hawthorne, D. J., Tingey, W. M., Naimov, S., Scott, J. G. 2012: Multiple evolutionary origins of knockdown resistance (kdr) in pyrethroid-resistant Colorado potato beetle, Leptinotarsa decemlineata. Pesticide Biochemistry and Physiology, 104: 192-200.

Schom, C. B., Abbot, U. K., Walker, N. 1973: Organophosphorus pesticide effect of domestic game bird species, Dursban. Poultry Science, 52: 2083.

Shanmugapriya, A. K. Sivakumar, T. Panneerselvam, R. 2013 Difenoconazole and Tricyclazole induced changes in photosynthetic pigments of Lycopersicon esculentum.L. International Journal of Agriculture and Food Science, 3(2): 72-75
Shono, T., Ohsawa, K., Casida, J. E. 1979: Metabolism of trans-permethrin and cis-permethrin, trans-cypermethrin, and cis-cypermethrin, and decamethrin by microsomal enzymes. Journal of Agriculture and Food Chemistry, 27: 316 .

Ural, M. Ş. and Sağlam, N. 2005: A study on the acute toxicity of pyrethroid deltamethrin on the fry rainbow trout (Oncorhynchus mykiss Walbaum, 1792). Pesticide Biochemistry and Physiology, 83: 124-131.

URL 2017: IUCN (http://www.iucnredlist.org). Date of access: 30.11.2017

US Environmental Protection Agency (USEPA), 1997: Imazamox, Pesticide Fact Sheet CAS No:114311-32-9. United States Enviromental Protection Agency, Washington, D.C. 20460.

US Environmental Protection Agency (USEPA), 2004: Mesosulfuronmethyl, TXR No:0052410. United States Enviromental Protection Agency, Washington, D.C. 20460

US Environmental Protection Agency (USEPA), 2008: Mandipropamid, Pesticide Fact Sheet CAS No: 34726-62-2. United States Enviromental Protection Agency, Washington, D.C. 20460

US Environmental Protection Agency (USEPA), 2010: Pyrethroids and pyrethrins,

<http://www.epa.gov/oppsrrd1/reevaluation/pyrethroidspyrethrins.html>.

US Environmental Protection Agency (USEPA), 2017: Difenoconazole Technical, CAS No: 119446-68-3. United States Enviromental Protection Agency, Washington, D.C. 20460.

Tanrıverdi Bahar, A. 2015: Mus İli Sınırları İçindeki Toy Kuşu (Otis tarda, L.1758)'nun Üreme Ekolojisi Üzerine Arastırmalar. Yüzüncü Yıl Üniversitesi Fen Bilimleri Enstitüsü, Yüksek Lisans Tezi, Van, Türkiye

Thomas, M. A. and Ibels, L. S. 1985: Rhabdomyolysis and acute renal failure, Australian and New Zealand Journal of Medicine, 15: 623-628.

Werner, I. and Moran, K. 2008: Effects of pyrethroid insecticides on aquatic organisms, In: Gan, J., Spurlock, F., Hendley, P., Weston, D.P. (Eds.), Synthetic Pyrethroids: Occurrence and Behavior in Aquatic Environments. American Chemical Society, Washington DC. pp. 310335.

WHO, 2011: Bentazone in drinking-water, WHO guidelines for Drinking water.

http://www.cepis.opsoms.org/bvsacg/e/cdcagua/guias/b.parameto s/3.RefB / quimicos/012. Bentazone/012bentazone.pdf

Wu, I. W., Wu, M. S., Lin, J. L. 2008: Acute renal failure induced by bentazone: 2 case reports and a comprehensive review. Journal of Nephrology, 21: 256-260.

Yang, Y., Ma, H., Zhou, J., Liu, J., Liu, W. 2014: Joint toxicity of permethrin and cypermethrin at sublethal concentrations to the embryo-larval zebrafish. Chemosphere, 96: 146-154.

Yarar, M. and Magnin, G. 1997: Türkiye'nin Önemli Kuş Alanları. Doğal Hayatı Koruma Derneği, İstanbul.

Yıldırım, M. Z., Benli, A. C. K., Selvi, M., Özkul, A., Erkoç, F., Kocak, O. 2006: Acute toxicity, behavioral changes, and histopathological effects of deltamethrin on tissues (Gills, Liver, Brain, Spleen, Kidney, Muscle, Skin) of Nile tilapia (Oreochromis niloticus L.) fingerlings. Environmental Toxicology, 21(6): 614-620. DOI:10.1002/ tox.20225. 